\title{
Parasites Associated with wild-caught houseflies in Awka metropololis
}

\author{
Nwangwu, U.C., Onyido, A.E., Egbuche, C.M, Iwueze, M.O. and Ezugbo- \\ Nwobi, I.K \\ Department of Parasitology and Entomology, Faculty of Biosciences, Nnamdi Azikiwe University, P.M.B 5025, \\ Awka, Anambra State, Nigeria.
}

\begin{abstract}
Investigation of parasites associated with wild-caught houseflies in Awka metropolis, Anambra State, southeastern Nigeria, was undertaken between April and August, 2012. Locally designed fly traps were used to collect flies. The flies were identified into genera and species using their characteristic features. These flies were demobilized by chilling, washed with sterilized distilled water, and the suspension homogenised before processing for parasites on their external body parts. For internal parasites, the external surfaces of the flies were sterilized with $70 \%$ alcohol, squashed to release the internal contents and the suspension homogenized with $100 \mathrm{ml}$ distilled water. Aliquots of the suspensions from both the internal and external contents of the flies were used for parasite isolations and identification using standard parasitological techniques. Eight fly species were processed for parasites identification. Parasites isolated from the flies were Entamoeba histolytica cysts, Hookworm ova, Ascaris lumbricoides ova, and Trichuris trichiura ova. All the parasites isolated were from the external surfaces of the flies. This reveals the fact that wild-caught flies, especially M. domestica, harbour parasites on their bodies, which can cause diseases. Hence, there is need for improved sanitation in our urban communities, to prevent epidemics associated with poor sanitary conditions.
\end{abstract}

Key words: Awka, Flies, Housefly, Parasites, Wild-caught.

\section{Introduction}

Muscoid flies have been linked with the transmission of bacteria, viruses, fungi, soil-transmitted helminthes (STH) and some protozoa. These parasitic diseases are relatively common in the slum and rural areas of many countries [1] and their high prevalence is closely associated to poverty, poor environmental sanitation, poor hygiene, and impoverished health services [2]. Defecation outside latrines by heavily infected persons have been recognized as the main source of the pathogens [3], while contaminated water, carriers, and food handlers might be the major transmission mode, of which indirect transmission by non-biting flies cannot be excluded [4, 5]. Many authors have indicated that primary school children are an ideal target group for STH [6], as they frequently defecate indiscriminately around their houses, particularly in the courtyards, sitting rooms, drains and bushes, even where every household has a latrine [7, 8]. Furthermore, some adults habitually excrete in the woods or groves not far from their houses [7, 9, and 10]. When infected persons excrete in open areas, there is an increased risk of contact between flies and pathogen-positive fecal matter [5]. Several studies have shown that eggs of Ascaris lumbricoides, Trichuris trichiura, hookworms (Ancylostoma duodenale and Necator americanus), Enterobius vermicularis, Capillaria hepatica, Taenia sp, Hymenolepis nana, Toxocara canis, and Strongyloides stercoralis larvae, are carried by many species of houseflies [5].

[11] had earlier observed that in addition to having external and internal structures particularly suited for picking up and transmitting parasites, the housefly has a habit of sucking up its nourishment from a wide variety of substances. These include contaminated materials from human and animal sources such as excreta, sputum, nasal secretions and secretions from sores and wounds. These flies also show equal fondness for food stuffs partaken of by man. This makes the houseflies outstanding important mechanical transmitters of public health diseases. [12] noted that houseflies thrive on excrement, dead animal bodies and contaminated areas, where faecal matter, large amount of organic wastes and piles of garbage are left exposed and unattended. [13] observed that muscoid flies are major epidemiologic factors responsible for the spread of acute gastroenteritis and trachoma among infants and young children in developing countries, as well as transmission of nosocomial infections with multiple antibiotic-resistant bacteria in hospital environments. [14] recognized that over 50 species of synanthropic flies are associated with unsanitary conditions and dissemination of human pathogens in the environment.

This study seeks to investigate parasites associated with wild-caught houseflies in Awka town. Specifically, it collected and identified flies from different ecological sites in Awka metropolis, as well as isolated and identified parasites associated with the wild-caught flies. 


\subsection{Study Area}

\section{Materials And Methods}

Awka is the political capital of Anambra State, South-east of Nigeria. Historically, Awka was the seat of the ancient Nri civilization governed by titled men known as Ozo and Ndichie who were accomplished individuals in the community. They held general meetings or "Izu Awka" either at the residence of the oldest man (Otochalu Awka) or at a place designated by him. He was the "Nne Uzu" or the Master Blacksmith. The city still preserves its traditional systems of governance with the "Ozos" (titled men) often consulted for village and community issues and a paramount traditional ruler, the "Eze Uzu", who is elected by all "Ozo" (titled men) by rotation amongst different villages to represent the city even at state functions.

Awka is geographically situated between latitude $6.22^{\circ} \mathrm{N}$ and longitude $7.07^{\circ} \mathrm{E}$ [15]. It lies within the flood plain of Udi escarpment and is drained into the River Niger by the Omambara River and its tributaries [15]. It is within the rainforest zone of Nigeria and has marked wet and dry seasons. The area has about eight months of rainfall (April - October), with an annual rainfall range of $2000-2030 \mathrm{~mm}$. The dry season lasts from November to March, with dry harmattan winds blowing for four to six weeks, between December and January or even February. It also has a daily temperature range of about $22.3-32.1{ }^{\circ} \mathrm{C}$ and a relative humidity range of about $68-79 \%$.

Awka has a population of 1,130,020 inhabitants [16]. The inhabitants of Awka are mainly Igbos, although there are few other groups, like the Hausas and Yorubas, who constitute a small percentage of the populace. It has three institutions of higher learning, including Nnamdi Azikiwe University, Paul's University, and Anambra State University Teaching Hospital. Also, it has 34 secondary schools and 76 primary schools. Other institutions in the city include the Anambra Broadcasting Service (ABS), a Television and Radio Station located in the city centre, while the privately owned Silver Bird Television and Rhythm FM stations are located in the outskirts of the city. A number of Federal Institutions including the Central Bank of Nigeria, the NTA Awka Media Station, and branch offices of the Federal Inland Revenue Service, Federal Road Safety Commission, Nigerian Immigration Service, and Corporate Affairs Commission are also present in the city. Major Nigerian Banks such as Access Bank, Fidelity Bank, Mainstreet Bank, Keystone Bank, Ecobank, First Bank, UBA, Union Bank, Zenith Bank, and Guaranty Trust Bank have branches in the city.

Occupationally, Awka was famous for blacksmith and woodwork - carving of objects like masks, stools and statues before the 20th century and their products were highly prized throughout the region [15]. They also produced farming implements, guns and tools. Awka was the seat of Nri civilization that produced the earliest documented bronze works in Sub-Saharan Africa around 800 A.D. [15]. In addition to craftsmanship, Awka is an agrarian community, practicing crop farming with keeping of animals, mostly at subsistence level. In recent years, several new businesses have been established in the city. Various organizations have erected fascinating new buildings that have largely changed the face of the city. The partly state-owned Orient Petroleum Resources Limited has its headquarters in Awka. The company has set up a refinery at Igbariam for exploitation and refining of the huge crude oil deposits in the Anambra River Basin. Also Juhel Nigeria Limited has constructed a huge manufacturing plant for the production of Parenteral drugs in the city.

The flies were collected with a specially designed trap made up of a transparent plastic bucket, about 10 cubic litres, manually perforated with tiny holes to provide adequate ventilation for the flies and fly bait. The fly baits were varied according to site. Dry and fresh fishes were used as baits in fish stalls, tomatoes were used as bait in tomato stalls, and pieces of meat were used as bait in the abattoir and meat stalls. Each trap (bucket with fly bait) was placed at a strategic place in the selected sites. As the flies were attracted to the bait inside the bucket, it was swiftly covered with its lid. The trapped flies were taken to the Parasitology and Entomology Laboratory of Nnamdi Azikiwe University, for identification and processing.

\subsection{Identification of the Flies}

The flies were identified into various species and groups using their gross morphological features [17, 4]. These morphological features included characteristic wing venation, presence or absence of squamae on the wings, hairy or bare arista, body markings, as well as hairs and bristles on certain body parts. These features were also used to separate the flies into groups like the muscoid flies, non-metallic calliphorines, metallic calliphorines, flesh flies, among others.

\subsection{Demobilizing the Flies}

In the laboratory the flies were demobilised by placing the fly traps and their contents inside a refrigerator or chest freezer (about $0^{\circ} \mathrm{C}$ ) to chill the flies. After about $20-40$ minutes, each bucket and its contents were removed from the chest freezer or refrigerator, and the chilled flies were collected. Using a sterilized pair of forceps, the flies were picked from the traps into clean sterile centrifuge/test tubes, to avoid contamination. 


\subsection{Preparation of flies for parasite isolation}

Ten chilled flies were dropped into a sterilized clean test tube or centrifuge tube containing about $10 \mathrm{ml}$ of distilled water and washed thoroughly by rocking (hand shaken) it from side to side for about 3 minutes to dislodge all parasites and their stages attached to the bodies of the flies into the water. The suspension resulting from washing of the flies was used to isolate the parasites and their stages attached to the bodies of the flies.

For the isolation of parasites inside the bodies of the flies, the flies were first surface-sterilized by placing them in 70\% ethanol, then rinsed in sterile water and crushed with a sterilised hand mortar and pestle to release the internal contents of the flies. Internal contents of the flies were homogenised with $100 \mathrm{ml}$ of sterile water and aliquots of the homogenates were used to isolate the parasites.

\subsection{Isolation of the parasites}

Two major parasitological techniques were employed for isolation of the parasites. These were flotation and sedimentation techniques.

\subsubsection{Flotation Technique (Zinc Sulphate solution)}

Zinc sulphate solution (1.18-1.20 specific gravity) was used for the study. The specific gravity of the solutions was determined using the hydrometer. A test tube half-filled with the suspension washed off the bodies of the flies, was filled to the brim with zinc sulphate solution. A clean, grease-free cover slip was placed on top of the tube with care to avoid trapping of air bubbles. The test tube was allowed to stand for 20 minutes, the cover slip carefully removed by pulling it upwards and placed face-downwards on a slide, and examined microscopically using a 10X objective. After, a drop of Lugol's iodine was dropped through the edge of the coverslip and examined with 40X objective to identify the cysts and eggs of helminths.

\subsubsection{Sedimentation Technique}

This method was employed for the detection of heavy trematode eggs, segments of cestodes, or whole organism that could have easily sank to the bottom of the test tube. A clean, sterile centrifuge tube half-filled with the suspension from washing of the flies was centrifuged at 2000r.p.m for two minutes. The supernatant was decanted and about 1 gram of the sediments placed on a clean glass slide, covered with a cover slip and examined under a 10X objective of the microscope. After, a drop of Lugol's iodine was dropped through the edge of the cover slip and it was reexamined under 40X objective lens to identify the cysts and eggs of helminths, especially trematodes.

\subsection{Identification of the parasites} features [18].

The parasites were identified into various species and groups using their shapes, sizes, and peculiar

\section{Results}

A total of 2,157 wild-caught flies from six different locations in Awka metropolis, where people bought and sold food stuffs either in their raw or already prepared states were used in this study. The sites (Table 1) were Bishop Crowther Area, characterized by many residential buildings, open-air defecation sites, fruit stalls, Paediatric hospital and a large undisposed refuse dump; Regina Caeli junction, has a concentration of restaurants; Aroma junction, which has a concentration of fruit stalls, open-air defecation sites and restaurants, Unizik temporary site junction, possesses a motor park, concentration of restaurants and food vendors and drainages littered with faeces; Awka Abattoir (Kwatta); which also serves as meat retail and wholesale markets, has open-air defecation sites; and Eke Awka, which is a large open market where all sorts of articles are sold, including raw and cooked food items, fruits, and vegetables.

The fly species collected from each location were also shown in Table 1. Eight fly species, namely, Musca domestica, Lucilia cuprina, Chrysomya bezziana, Fannia canicularis, Wohlfarhtia species, Stomoxys calcitrans, Sarcophaga species and Musca sorbens, were collected from various locations. Musca domestica was most widely distributed in all the locations. Of the eight fly species, 7 were collected from Bishop Crowder Area, 5 species from the Abattoir and Eke Awka market areas respectively, 4 species from Unizik temporary site, and 3 species each from Regina Caeli and the Aroma junction Areas, respectively.

Of the 8 fly species collected (Table 2), M. domestica was the most prevalent 1,824 (84.60\%), followed by L. cuprina 173 (8.0\%), C. bezziana 63 (2.90\%), M. sorbens 32(1.50\%), Sarcophaga species 28 (1.3\%), Worhlfarhtia species $12(0.60 \%)$ and S. calcitrans $5(0.20 \%)$.

The features of identification of the flies were shown in Table 3. M. domestica was recognised as a dull-grey, medium sized fly with 4 longitudinal black markings at the back of the thorax and a wing venation in which the $4^{\text {th }}$ longitudinal vein bends sharply to vein 3 leaving a narrow open cell between veins 3 and 4 . The Lesser housefly, Fannia canicularis was identified by its small size, grey black colour, with three indistinct 
black stripes at the back of the thorax and convergent anal wing veins. The legs are black and the halters, yellow. L. cuprina was identified by its metallic green femoral joint in the first pair of legs, possession of one occipital setae and bare squamae. Sarcophaga species was recognized as a generally large sized, ash-grey coloured fly, with 4 longitudinal dark stripes at the back of the thorax and dark and light square dots on the abdomen. Large-size, striped but greyish thorax and an abdomen whose dorsal surface is bright white with a series of three contrasting dark black spots per tergite, was used to identify Wohlfarhtia species. Chrysomya bezziana was identified by its typical metallic green or blue colour often mixed with copper colour and several dorsal bristles on the thorax. The fly is robust, typically yellow-faced with soft fine yellow hairs. The abdominal tergites have narrow darker bands and the legs are black or dark-brown, while the wings have a glassy appearance. Musca sorbens, was identified as a small, dull-grey fly, which has 2 dark stripes on the back of its thorax. Stomoxys calcitrans was identified as a medium sized, grey coloured fly, which has prominently projecting proboscis, with four longitudinal stripes on the back of the thorax. The abdomen is short, broad and has three dark spots on the second and third segments.

The parasites isolated from different fly species were shown in Table 4. Four parasite species or their stages were isolated from the flies collected from different ecological locations in the city. They are Entamoeba histolytica cysts, Hookworm ova, Ascaris lumbricoides ova and Trichuris trichiura eggs. The parasites were isolated from flies collected from four locations namely, Regina Caeli junction, UNIZIK Temporary site area, Abattoir and Eke Awka market. No parasite was isolated from flies collected at Bishop Crowther and Aroma junction areas. Ascaris lumbricoides eggs were isolated from flies caught in all the four location where parasites were found. E. histolytica cysts were isolated from flies collected at Regina Caeli and Eke Awka market areas. Hookworm ova were isolated from flies collected at Regina Caeli and the Abattoir. While T. trichiura ova were isolated only from flies collected at Eke Awka market.

The features of identification of the parasites are shown in Table 5. Ascaris ova were identified by their spherical shape with thick lumpy outer shell. Hookworm ova have very delicate thin wall, oval in shape and contain embryo in 4 or 8 celled stage of their division. The T. trichuris eggs were barrel-shaped, with bipolar plugs and thick-shelled walls. Entamoeba cysts were spherical in shape and possessed four nuclei. All the parasites were isolated from only the external washings of Musca domestica (Table 6).

Table 1: Study sites and fly species collected from them

\begin{tabular}{|c|c|c|c|c|}
\hline $\mathrm{S} / \mathrm{N}$ & $\begin{array}{l}\text { Location In Awka } \\
\text { metropolis }\end{array}$ & Nature of Site & $\begin{array}{c}\text { Number of times } \\
\text { sampled }\end{array}$ & Fly species caught \\
\hline 1. & Bishop Crowther & $\begin{array}{l}\text { Open-air defecation } \\
\text { sites, human homes, } \\
\text { fruit stalls, Paediatric } \\
\text { hospital with huge } \\
\text { undisposed refuse dump }\end{array}$ & 5 & $\begin{array}{c}\text { Musca domestica, Lucilia } \\
\text { cuprina, Chrysomya bezziana, } \\
\text { Wolfarhtia species, Fannia } \\
\text { canicularis, Stomoxys } \\
\text { calcitrans, \& Sarcophaga } \\
\text { species }\end{array}$ \\
\hline 2. & $\begin{array}{c}\text { Regina Caeli } \\
\text { Junction by Zik's } \\
\text { Avenue }\end{array}$ & $\begin{array}{l}\text { Concentration of } \\
\text { popular restaurants }\end{array}$ & 5 & $\begin{array}{l}\text { Musca domestica, Musca } \\
\text { sorbens, \& Lucilia cuprina }\end{array}$ \\
\hline 3. & Aroma junction & $\begin{array}{l}\text { Open-air defecation } \\
\text { sites, fruit stalls, } \\
\text { restaurants and a motor } \\
\text { park }\end{array}$ & 5 & $\begin{array}{c}\text { Musca domestica, Lucilia } \\
\text { cuprina, \& Sarcophaga species }\end{array}$ \\
\hline 4. & $\begin{array}{l}\text { UNIZIK Temporary } \\
\text { Site }\end{array}$ & $\begin{array}{l}\text { Concentration of } \\
\text { Eateries, restaurants } \\
\text { and motor parks, } \\
\text { drainages littered with } \\
\text { faeces }\end{array}$ & 5 & $\begin{array}{l}\text { Musca domestica, Musca } \\
\text { sorbens, Lucilia cuprina, } \\
\text { Chrysomya bezziana }\end{array}$ \\
\hline 5. & Abattoir (Kwatta) & $\begin{array}{l}\text { State capital's main } \\
\text { meat stall, surrounded } \\
\text { by bushes utilized for } \\
\text { indiscriminate } \\
\text { defecation }\end{array}$ & 5 & $\begin{array}{c}\text { Musca domestica, Musca } \\
\text { sorbens, Lucilia cuprina, } \\
\text { Chrysomya bezziana, Stomoxys } \\
\text { calcitrans }\end{array}$ \\
\hline 6. & Eke Awka Market & $\begin{array}{l}\text { Fruit and vegetable } \\
\text { stalls, restaurants, food } \\
\text { vendors and assorted } \\
\text { food stuffs }\end{array}$ & 5 & $\begin{array}{l}\text { Musca domestica, Musca } \\
\text { sorbens, Sarcophaga species, } \\
\text { Chrysomya bezziana \& } \\
\text { Stomoxys calcitrans }\end{array}$ \\
\hline Total & 6 & 6 & 30 & 8 \\
\hline
\end{tabular}


Table 2: Number and percentage of identified fly species

\begin{tabular}{|c|c|c|c|}
\hline S/n & Fly Species & Number & Percentage (\%) \\
\hline 1. & Musca domestica & 1,824 & 84.6 \\
\hline 2. & Fannia canicularis & 20 & 0.9 \\
\hline 3. & Lucilia cuprina & 173 & 8 \\
\hline 4. & Sarcophaga species & 28 & 1.3 \\
\hline 5. & Wolfarhtia species & 12 & 0.6 \\
\hline 6. & Chrysomya bezziana & 63 & 2.9 \\
\hline 7. & Musca sorbens & 32 & 1.5 \\
\hline 8. & Stomoxys calcitrans & 5 & 0.2 \\
\hline Total & 8 & 2,157 & 100 \\
\hline
\end{tabular}

Table 3: Features of identification of the wild-caught flies

\begin{tabular}{|l|c|l|c|}
\hline S/N & Fly species & \multicolumn{1}{|c|}{ Features of Identification } & $\begin{array}{c}\text { Lenght } \\
\text { (mm) }\end{array}$ \\
\hline 1. & Musca domestica & $\begin{array}{l}\text { Medium sized, dull-grey fly with 3-segmented antenna with } \\
\text { dorsal arista, wing venation in which longitudinal vein 4 bends } \\
\text { sharply to vein 3, leaving a narrow open cell between them. } \\
\text { Thorax has 4 distinct longitudinal lines. }\end{array}$ & $6-8$ \\
\hline 2. & Fannia canicularis & $\begin{array}{l}\text { Small sized, grey black colour with three indistinct black stripes } \\
\text { along the thorax and convergent anal wing veins. The legs are } \\
\text { black and the halters, yellow }\end{array}$ & $3.5-6$ \\
\hline 3. & Lucilia cuprina & $\begin{array}{l}\text { Relatively large fly, has metallic green femoral joint in the first } \\
\text { pair of legs and bare squamae }\end{array}$ & $5-10$ \\
\hline 4. & Sarcophaga species & $\begin{array}{l}\text { Generally large-sized fly, ash grey colour, with 4 longitudinal } \\
\text { dark stripes on the thorax, as well as dark and light square dots } \\
\text { on the abdomen }\end{array}$ & $12-18$ \\
\hline 5. & Wohlfahrtia species & $\begin{array}{l}\text { Large sized fly, striped greyish thorax with abdomen whose } \\
\text { dorsal surface is bright white and with a series of contrasting } \\
\text { dark black spots, three per tergite }\end{array}$ & $9-10$ \\
\hline 6. & Chrysomyia bezziana & $\begin{array}{l}\text { Robust, metallic green or blue fly often mixed with copper } \\
\text { colour, yellow-faced with soft fine yellow hairs and glassy } \\
\text { wings. The dorsal bristles of the thorax are few }\end{array}$ & $7-11$ \\
\hline 7. & Musca sorbens & Small, dull-grey fly, with 2 dark stripes on the thorax & $3.5-6$ \\
\hline 8. & Stomoxys calcitrans & $\begin{array}{l}\text { Medium sized fly, with prominently projecting proboscis, grey } \\
\text { in colour, four longitudinal stripes on the thorax, abdomen is } \\
\text { short, broad and has three dark spots on the second and third } \\
\text { segments }\end{array}$ & $4-8$ \\
\hline
\end{tabular}

Table 4: Parasites isolated from the wild-caught flies

\begin{tabular}{|c|c|c|c|}
\hline S/N & $\begin{array}{c}\text { Locations in Awka } \\
\text { metropolis }\end{array}$ & Number of times sampled & Parasites detected \\
\hline 1. & Bishop Crowther & 5 & NIL \\
\hline 2. & Regina Caeli Junction & 5 & $\begin{array}{c}\text { Entamoeba histolytica cyst, } \\
\text { Hookworm ova, and Ascaris } \\
\text { lumbricoides ova (fertilized) }\end{array}$ \\
\hline 3. & Aroma junction & 5 & NIL \\
\hline 4. & UNIZIK Temporary Site & 5 & $\begin{array}{c}\text { Ascaris lumbricoides } \\
\text { ova(fertilized) }\end{array}$ \\
\hline 5. & Abattoir (Kwatta) & 5 & $\begin{array}{c}\text { Ascaris lumbricoides ova } \\
\text { (fertilized), and Hookworm ova }\end{array}$ \\
\hline 6. & Eke Awka Market & 5 & $\begin{array}{c}\text { Ascaris lumbricoides } \text { ova } \\
\text { (fertilized) and Entamoeba } \\
\text { histolytica cyst, and Trichuris } \\
\text { trichiura ova. }\end{array}$ \\
\hline
\end{tabular}


Table 5: Features of identification of the parasites

\begin{tabular}{|l|l|}
\hline Parasite & Features of Identification \\
\hline Ascaris lumbricoides egg & $\begin{array}{l}\text { Fertilized eggs are oval to round, and has thick lumpy outer shell } \\
\text { (mammillated or proteinaceous layer). This layer is usually bile-stained or } \\
\text { golden brown. Unfertilized eggs are narrower and longer, lacking the } \\
\text { fertilizing membrane. }\end{array}$ \\
\hline Hookworm egg & $\begin{array}{l}\text { It is delicately thin-shelled, oval or ellipsoidal shaped; contains an embryo in } \\
\text { the 4 to 8-cell stage of division. It also has a clear halo around the embryo, } \\
\text { which has granular appearance. }\end{array}$ \\
\hline Trichuris trichiura egg & $\begin{array}{l}\text { Eggs are barrel-shaped, unembryonated, having bipolar plugs (tray-shaped), } \\
\text { and a thick smooth shell. }\end{array}$ \\
\hline Entamoeba histolytica cyst & It is spheroid, compact and has four nuclei. \\
\hline
\end{tabular}

Table 6: Parasites isolated from the external and internal body parts of flies

\begin{tabular}{|l|l|c|c|c|c|}
\hline $\begin{array}{l}\text { S/ } \\
\text { N }\end{array}$ & Parasites isolated & $\begin{array}{l}\text { External body } \\
\text { surface of } M . \\
\text { domestica }\end{array}$ & $\begin{array}{l}\text { Internal body } \\
\text { parts of } M . \\
\text { domestica }\end{array}$ & $\begin{array}{l}\text { External body } \\
\text { surfaces of } \\
\text { other flies }\end{array}$ & $\begin{array}{l}\text { Internal } \\
\text { body parts } \\
\text { of other flies }\end{array}$ \\
\hline 1. & $\begin{array}{l}\text { Ascaris } \\
\text { lumbricoides ova }\end{array}$ & $\mathrm{X}$ & - & - & - \\
\hline 2. & $\begin{array}{l}\text { Entamoeba } \\
\text { histolytica cyst }\end{array}$ & $\mathrm{X}$ & - & - & - \\
\hline 3. & Hookworm ova & $\mathrm{X}$ & - & - & - \\
\hline 4. & $\begin{array}{l}\text { Trichuris trichiura } \\
\text { ova }\end{array}$ & $\mathrm{X}$ & - & - & - \\
\hline
\end{tabular}

' $\mathrm{X}$ ' indicates presence of a parasite stage

'-' indicates absence of a parasite stage

\section{Discussion And Conclusion}

A total of 2,157 wild-caught flies comprising of eight species were collected from 6 locations in Awka where food items, fruits and vegetables were sold in both raw and cooked states. This shows that the flies are abundant in the area, probably due to the existence of favourable breeding sites and tropical climate which increases their rate of development.

Eight fly species were collected in the study with $M$. domestica being the most prevalent (84.60\%), while $S$. calcitrans was the least $(0.20 \%)$. This shows that the environment can support different species of flies leading to high species diversity in the area. [14] showed that over 50 species of synanthropic flies have been reported to be associated with unsanitary conditions and are involved in dissemination of human pathogens in the environment.

Houseflies were found to harbour three soil-transmitted helminths (STH) eggs (Trichuris trichiura, Ascaris lumbricoides, and hookworm) and a protozoan cyst (Entamoeba histolytica) all on its external body surfaces. The results are similar to the findings of [19] and [20], who isolated parasites from both the external and internal organs of houseflies. Also, [12], found Hookworm eggs and larvae in the gut of flies, but found more on external surfaces. [5] have reported higher parasite detection rates in the gastrointestinal lumen than on body surface. The observation of T. trichiura and A. lumbricoides eggs, as well as hookworm ova, on the flies corroborates the findings of [20], that houseflies are mechanical transmitters of soil-transmitted helminths. These authors also observed that the flies could carry and spread parasites and pathogens to other places, since they are able to travel up to 20 miles to unsanitary sites.

Parasites were isolated from flies collected from 4 of the 6 locations. This is an indication that flies infested with the parasites may be widespread throughout the area of study. These are likely to be deposited in human food as the flies forage. [13] showed that houseflies among other synanthropic flies are major epidemiologic factors responsible for the spread of many diseases among infants and young children in developing countries and transmission of nosocomial infections in hospital environments.

Ascaris lumbricoides was the most prevalent parasite isolated from flies collected from different fly collection sites. This is in agreement with the findings of [10], who in a study in Ban Nam Khem village, Thailand, revealed that $A$. lumbricoides eggs were found in all samples collected for the studythis indicates that most parts of the city may be littered with helminths infested faeces. [6] showed that children are an ideal target group for Soil Transmitted Helminth as they frequently defecate indiscriminately around their houses, particularly in the courtyards, sitting rooms, drains and bushes, even where every household has a latrine. [21] observed that this condition may predispose the area for breeding of the flies and exposure of the inhabitants to fly-borne diseases. [12] observed that houseflies thrive on excrement, dead animal bodies, and contaminated areas where faecal matter, large amounts of organic waste and piles of garbage are left exposed and unattended. 
The parasites isolated from this study are of great medical and public health importance. Chronic infection with hookworm leads to iron deficiency anaemia, listlessness, pallor, and general retardation of development of afflicted children [22]. In moderate and heavy infections, A. lumbricoides has been recorded to cause malnutrition, underdevelopment and cognitive impairment in children [23]. It also causes intestinal blockage, insomnia, restlessness, lung damage, and peritonitis [24]. In moderate and heavy infections, $T$. trichiura causes dysentery, anaemia, growth retardation, finger clubbing, rectal prolapse, and adversely affects the cognitive function in children [25]. Amoebiasis which is caused by E. histolytica is the second leading cause of death from parasitic diseases worldwide, as it is estimated that about 40,000 to 100,000 people die due to the disease annually [26]. It causes dysentery, liver abscess, perforation of the colon, bowel obstruction, intestinal ulceration, and poor development [18].

All four parasite species were isolated from wild-caught $M$. domestica. These results indicate that houseflies are potential mechanical vectors of parasitic diseases of public health importance. [27] demonstrated that synanthropic and coprophilic adult flies with access to a substrate containing parasites can transport and probably transmit them in their internal and on their external body surfaces. In most of the rural and urban areas like Awka metropolis, where there are some undisposed refuse dumps and open-air defecation, efforts should be geared towards sensitization of the public on the potential dangers posed by filth flies. Hence, there is the need for improved personal hygiene and environmental sanitation, which will reduce the likelihood of spreading diseases or infections by the flies. In areas where open-air defecation is common, food must be strictly protected from filth flies, particularly the housefly which harboured all the parasites isolated in this study. However, open - air defecation and other unsanitary conditions which provide breeding sites for the flies in the community must be discouraged through proper sanitary practices.

\section{References}

[1]. B.M. Che-Ghani, P. Oothuman, B.B. Hashim and B.I. Rusli, Patterns of hookworm infections in traditional Malaysia villages with and without JOICFP Integrated Project in Peninsular Malaysia-1989. Collected papers on the control of soiltransmitted helminthiases, Vol. V. APCO, Tokyo, 1993, Pp. 14-21.

[2]. A. Montresor, D.W.T. Crompton, A. Hall, D.A.P. Bundy and L. Savioli, Guidelines for the evaluation of soil-transmitted helminthiasis and schistosomiasis at community level, 1998. WHO/CTD/SIP/98.1

[3]. K.E. Mott, The World Health Organization and the control of intestinal helminths. Collected papers on the control of soiltransmitted helminthiases, Vol. IV. Tokyo: APCO, 1989, Pp. 189-200.

[4]. A.C. Chandler and C.P. Read, Introduction to parasitology with special references to the parasites of man. 10th ed. (John Wiley \& Sons; New York, 1962).

[5]. S. Getachew, T. Gebre-Michael, B. Erko, M. Balkew and G. Medhin,. Non-biting cyclorrhaphan flies (Diptera) as carriers of intestinal human parasites in slum areas of Addis Ababa, Ethiopia. Acta Tropica. 103: 2007, 186-94.

[6]. D.A.P. Bundy, A. Hall, G.F. Medley and L. Savioli, Evaluation measures to control intestinal parasitic infections. World Health Stat Q. 45: $1992,168-79$.

[7]. K.P.F. Lai and C.K. Ow-Yang, Soil-transmitted helminthiasis in a rubber and oil-palm estate in Selangor Peninsular, Malaysia. Collected papers on the control of soil-transmitted helminthiases, Vol. V. Tokyo: APCO, 1993, Pp. 72-7.

[8]. S. Yu, L. Xu, Z. Jiang, Q. Chai, C. Zhou and Y. Fang, Environmental and human behavioral factors in propagation of soiltransmitted helminth infections. In: Yokogawa M, et al, editors. Collected papers on the control of soil-transmitted helminthiases, Vol. V. Tokyo: APCO, 1993, Pp. 83-8.

[9]. M.T. Anantaphruti, J. Waikagul, W. Maipanich, S. Nuamtanong and S. Pubampen, Soil-transmitted helminthiases and health behaviours among schoolchildren and community members in a west-central border areas of Thailand. Southeast Asian J Trop Med Public Health. 35: 2004, 260-6.

[10]. W. Maipanich, S. Sanguankiat, S. Pubampen, T. Kusolsuk, W. Rojekittikhun and F. Castelli, Helminthic infections in a Tsunamiaffected area: soil contamination and infection rates in the population. J Trop Med Parasitol. 30: 2007, 5-11.

[11]. R.M. Gordon and M.M.J. Lavoipierre, Entomology for students of medicine. (Blackwell Scientific Publication, Oxford, London, Edinburgh and Melbourne, 1976)

[12]. S. Sulaiman, C.G. Mohammod, M.A. Marwi and P. Oothuman, Study on the role of flies in transmitting helminths in a community. In: Yokogawa M, et al, editors. Collected papers on the control of soil-transmitted helminthiases, Vol. IV. Tokyo: APCO, 1989, Pp. 59-62.

[13]. T. Graczyk, R. Cranfield and H. Cranfield, The role of non-biting flies in the epidemiology of human infectious diseases. Microbes and Infection. 3: 2001, 231-235.

[14]. A. Olsen, Regulatory action criteria for filth and other extraneous materials. III. Review of flies and food-borne enteric diseases. Regulat Toxicol and Pharmacol. 28: 1998, 199-211.

[15]. N.P. Iloeje, A new geography of Nigeria (Longman Nigeria Ltd., Nigeria, 2001, Pp. 206).

[16]. N.P.C., Nigerian National Population Census - Official Gazette (FGP 71/52007/2,500 (OL24): 2006, Pp. 2.

[17]. M.W. Service, A guide to medical Entomology (MacMillan Press Ltd., London, 1980, Pp. 102-109).

[18]. G.D. Schmidth and L.S. Roberts, Foundations of Parasitology, $6^{\text {th }}$ Edition. (McGraw Hill, New York, 2000, Pp 107, 586-592).

[19]. T. Graczyk, R. Cranfield, R. Fayer and H. Bixler, Houseflies (Musca domestica) as transport hosts of Cryptosporidium parvum. Am J Trop Med Hyg. 61: 1999, 500-504.

[20]. N. Umeche and L.E. Mandah, Musca domestica as a carrier of intestinal helminths in Calabar, Nigeria. East Afr Med J. 66: 1989, 349-52.

[21]. A.E. Onyido, P.O. Okolo, M.O. Obiukwu and E.S. Amadi, A survey of vectors of public health diseases in undisposed refuse dumps in Awka, Anambra State Southeastern Nigeria. Research Journal of Parasitology. 4(1), 2009, $22-27$.

[22]. L.R. Ash and T.C. Orihel, Tissue Helminths. Manual of Clinical Microbiology. 8th ed. Vol. 2. ASM Press, Washington DC, 2003, Pp. 2031-2046. 
[23]. M. Levav, A.F. Mirsky, P.M. Schantz, S. Castro and M.E. Cruz, Parasitic infecton in malnourished school children: Effects on behaviour and EEG. Parasitology 110: 1995, 103-111.

[24]. J.K. Baird, M. Mistery, M. Pimsler and D.H. Connor, Fatal human Ascariasis following secondary massive infection. Am. J. Trop. Med. Hyg. 35: 1986, 314-318.

[25]. C. Nokes, S.M. Grantham-McGregor, A.W. Sawyer, E.S. Cooper, B.A. Robinson and D.A.P. Bundy, Moderate to heavy infections of Trichuris trichiura affect cognitive function in Jamaican school children. Parasitology 104: 1992, 539-547.

[26]. F.L. Heiman, P. H. Wertheim and J. P. Woodall,. Atlas of Human Infectious Diseases, First Edition. (Blackwell Publishing Ltd. 2012, Pp 126).

[27]. S. Sulaiman, M.Othman and A. Aziz, Isolations of enteric pathogens from synanthropic flies trapped in downtown Kuala Lumpur. $J$ Vect Ecolo. 25: 2000, 90-93. 